УДК 32.09 .51

DOI: $10.17223 / 1998863 \mathrm{X} / 56 / 22$

\title{
Г.Е. Боброва
}

\section{ЭВОЛЮЦИЯ ИМИДЖА В.В. ПУТИНА В «DER SPIEGEL» В КОНТЕКСТЕ УКРАИНСКОГО КРИЗИСА}

\begin{abstract}
Имидж В. Путина рассматривается в контексте отражения в «Der Spiegel» важнейших событий украинского кризиса, прежде всего, присоединения Крыма к России, их влияния на качественные характеристики имиджа российского президента, зависимости составляющих образа главы РФ от субъектов конструирования этого образа: противники, понимающие Путина и скептики.

Ключевые слова: имидж В. Путина, Spiegel, Крым, демонизация, тенденция, противники, путинопониматели, скептики.
\end{abstract}

В начале 2012 г. журналисты «Der Spiegel» предрекая В.В. Путину непростой третий президентский срок, акцентировали внимание на внутриполитической ситуации в России, на протестных настроениях и митингах в Москве и Санкт-Петербурге. Но уже в 2014 г. фокус их интереса сместился в область внешней политики России, которая стала играть роль доминирующего фактора конструирования образа российского президента в одном из самых значимых информационно-политических журналов Германии и Европы. Совокупная аудитория «Der Spiegel» насчитывает 5 млн человек [1], позволяя ему оказывать серьезное влияние на формирование общественного мнения в регионе относительно наиболее важных вопросов международной политики и ее ключевых фигур.

Цель статьи - выявить тенденции эволюции внешнего имиджа В.В. Путина в «Der Spiegel» в аспекте событий на Украине.

Данная статья представляет собой продолжение анализа имиджа B.В. Путина в «Der Spiegel», впервые предпринятого нами в 2014 г. [2]. Coхраняется алгоритм исследования, теоретической основой которого выступает представление об имидже как целенаправленно формируемом образе политического лидера, включающем три группы составляющих [3]:

- персональные характеристики, в том числе физические, психофизиологические особенности, характер, тип личности, индивидуальный стиль принятия решений;

- социальные характеристики - статус лидера, его модели ролевого поведения, связь с различными социальными группами, интересы которых он представляет, а также с союзниками, оппонентами и явными врагами;

- культурно-символические характеристики - идеалы, ценности, представления о мире.

Работая над темой в рамках теории политической коммуникации, мы обращались к публикациям, объектом изучения которых является международный имидж России в СМИ различных стран и одновременно значительное внимание уделяется президенту РФ, роли его личности в имидже страны [4]; к исследованиям, сфокусированным конкретно на анализе образа В.В. Пути- 
на в зарубежных mass-media [5], а также к медиатекстам немецкого еженедельника «Der Spiegel».

Отмечая общие моменты в наших исследованиях имиджа российского президента в данной статье и в 2014 г., обратим внимание и на различия между ними.

Во-первых, в 2014 г. имидж В.В. Путина в «Der Spiegel» изучался в период трех президентских избирательных кампаний, сейчас - на относительно непродолжительном временном интервале - с 2014 по осень 2015 г. Выбор нижней границы связан с присоединением Крыма, которое можно рассматривать в качестве разграничительной линии в истории постсоветской России как с точки зрения ее положения в системе международных отношений, так и в аспекте внутреннего и внешнего имиджа российского президента и страны в целом. Осень 2015 г. в качестве верхнего предела нашего исследования выбрана в связи с тем, что с этого времени Украина «уходит» из эпицентра внимания западных СМИ и оказывается «в тени» сирийского конфликта.

Второе различие касается источниковой базы исследования. В 2014 г. она состояла из 57 статей журналистов «Der Spiegel» в авторском переводе с немецкого языка. В данном исследовании мы использовали два информационных ресурса, специализирующихся на переводах материалов зарубежных изданий: инопресса и иноСМИ. Это обеспечило более емкое представление об информации в немецком еженедельнике, поскольку ключевые статьи, отобранные для перевода, далеко не всегда в них совпадают и отличаются его качеством. Сохранена структура и точно передано содержание оригинала в иноСМИ. Дополнительное преимущество этого ресурса - полный перевод интервью с политиками, государственными деятелями, лидерами мнения, в то время как Инопресса ограничивается аннотацией основного содержания беседы. Вместе с тем Инопресса более мобильна с точки зрения предоставления информации и количества материалов.

216 статей, размещенных за полтора года на указанных ресурсах и имеющих отношение к России, были проанализированы в формате кратких резюме на основе метода содержательного контент-анализа по таким переменным, как дата, автор, жанр, проблема, ключевые слова, включая фамилию президента. Из общего перечня медиатекстов были отобраны 80, в которых встречается имя В.В. Путина или слова-заменители, смысл которых не вызывает сомнения, о ком идет речь, и относящиеся к объекту исследования имиджу российского президента в «Der Spiegel». Дальнейшая их обработка проводилась на основе двух комплексов зависимых переменных. В первом учитывалось количество статей по тем переменным, которые указаны выше. Во втором комплексе зависимых переменных принималось во внимание качество статей на основании суждений о том, чьи позиции репродуцировали обществу журналисты: противников президента, понимающих Путина или скептиков. Организованная и систематизированная таким образом информация позволила проследить зависимость качественных характеристик имиджа В.В. Путина от субъектов конструирования этого имиджа, выявить основные тренды и имидж-факторы в этом процессе.

Журналистский корпус, освещающий события, связанные с Россией, был представлен, прежде всего, аккредитованными в ней корреспондентами, среди которых такие «тяжеловесы», как Б. Биддер и К. Нееф, долгое время про- 
жившие в Москве (10 и 30 лет соответственно), знавшие ситуацию изнутри, перу которых принадлежала львиная доля материалов о России. Помимо них, более 30 журналистов «Der Spiegel» представили широкий спектр мнений о российском президенте, на основе которых моделировался и презентовался имидж В. Путина немецкому и шире - европейскому сообществу. Сказанное позволяет выйти за рамки устоявшегося представления о том, что западные СМИ демонизируют образ российского президента. Действительно, такая тенденция в эволюции имиджа главы РФ является доминирующей, но ее основу составляют представления о Путине его противников. Между тем «Der Spiegel» обращается к позициям и других групп: назовем их «путинопониматели» и скептики. И это совсем другой коленкор с точки зрения качественных характеристик имиджа российского президента.

На формирование имиджа главы государства в иностранных СМИ оказывают влияние различные факторы. Одним из важнейших является его политический курс. Если в первые два срока правления В. Путина (2000-2004, 2004-2008) оценка внутренней политики России была базовой для конструирования его имиджа в «Der Spiegel», то на третьем ключевая роль принадлежала уже внешней. Точкой отправления для этого стали события на Украине: присоединение Крыма к России и конфликт на востоке страны.

Украинский кризис оказал решающее влияние на эволюцию имиджа В. Путина в период его третьего срока правления, поскольку задал вектор оценок внешней политики и имиджевых характеристик российского президента, причем диаметрально противоположных внутри России и за ее пределами. Прежде всего это касается Крыма.

Немецкие журналисты проявили почти полное единодушие, рассматривая включение полуострова в состав РФ как аннексию и нарушение норм международного права. При этом в материалах «Der Spiegel» представлена и более радикальная позиция, квалифицирующая этот факт как аншлюс. Так, 3. Бжезинский (бывший советник по безопасности президента Джимми Картера), выступая за поставки оружия на Украину и рассматривая их как симметричный ответ западных стран на действия Путина, напомнил о всеобщей пассивности после ввода гитлеровских войск в Судеты и после «аншлюса» Австрии [6]. Параллель между действиями Путина и Гитлера провела $\mathrm{X.} \mathrm{Клинтон} \mathrm{[7].} \mathrm{Подчеркнем,} \mathrm{что} \mathrm{подобные} \mathrm{суждения} \mathrm{не} \mathrm{получили} \mathrm{широкого}$ распространения. Более того, еженедельник приводит диаметрально противоположное мнение Г. Киссинджера (советник по национальной безопасности и государственный секретарь в администрации Р. Никсона и Джеральда Форда), согласно которому «Крым - это особый случай... Аннексия Крыма не была шагом в сторону глобального завоевания. Это не вхождение Гитлера в Чехословакию» [8].

Не обходят вниманием журналисты «Der Spiegel» и точку зрения тех, кто в присоединении Крыма к России видит разумную реакцию Москвы на расширение НАТО на Восток. Например, бывший канцлер Германии Г. Шмидт открыто заявил, что «на месте Путина среагировал бы так же в отношении Крыма», еще один экс-канцлер Г. Шредер признался, что и сам не всегда придерживался норм международного права [9].

Несмотря на различные позиции по Крыму, представленные в еженедельнике, центральный тезис об аннексии полуострова Россией и нарушении 
ею порядка, установленного после окончания «холодной войны», проводится весьма последовательно, особенно когда речь идет о последствиях этого события.

Рассматривая отношения между РФ и Западом, немецкие журналисты используют различные логико-грамматические конструкции, четко маркирующие происходящие события как реакцию на присоединение полуострова: после российского вторжения на о. Крым, до аннексии Крыма, в связи с аннексией Крыма, с начала крымского кризиса, после присоединения Крыма, разногласия по поводу Крыма и др. Таким образом, Крым стал своеобразным Рубиконом, который поделил отношения Запада с Россией на «до» и «после» вхождения полуострова в состав Российской Федерации.

В материалах «Der Spiegel» четко прослеживаются две позиции по отношению к России в посткрымский период: жесткая, инициированная президентом Обамой и ориентированная на отказ от переговоров, возвращение к стратегии сдерживания, увеличение военных расходов европейских стран, широкомасштабные санкции и изоляция В. Путина; и мягкая, предполагающая сохранение диалога с Россией, проводниками которой выступали некоторые европейские страны, в первую очередь Германия, играющая главную роль в вопросе дипломатического урегулирования российско-украинского конфликта.

Журналисты обращают внимание на то, что основой для проведения первой, помимо Крыма и войны на востоке Украины, послужили также страхи прибалтийских республик и Польши о российском вторжении, дискуссии о дееспособности НАТО обеспечить их безопасность, настойчивое требование увеличения присутствия НАТО в Европе, восстановление тыловой инфраструктуры Североатлантического альянса в регионе. В еженедельнике представлена целая серия интервью корреспондентов «Spiegel» с государственными и политическими деятелями (действующими и бывшими), в которых затрагиваются указанные проблемы.

Так, по словам президента Литвы Дали Грибаускайте, после вторжения России в Крым она не исключает подобного в отношении собственной страны [10]. По мнению экс-главы ЦРУ Леона Панетты, Украина будет только первым шагом, если не дать понять Путину, что за дальнейшую агрессию он заплатит высокую цену. Апеллируя к своему политическому опыту, он утверждает, что с русскими можно вести переговоры только с позиций силы [11].

Заместитель верховного главнокомандующего войсками НАТО в Европе до 2014 г. британский генерал Ричард Шиффер, автор нашумевшего триллера о вымышленной войне с Россией, настойчиво проводит мысль о российской угрозе и необходимости активизации деятельности Североатлантического альянса по защите территории своих членов, в том числе Прибалтики, и заключает: «Давно пора Европе воспринять аннексию Крыма как сигнал к пробуждению» [12].

В рамках этой позиции наметилась тенденция демонизации образа В. Путина. «Европа привыкла демонизировать российского президента В. Путина и сваливать на него ответственность за все мировое зло... От конфликта на Украине вплоть до миграционного кризиса и движения Pegida: российского президента обвиняют во всем, что на континенте идет не так», - 
охарактеризовал эту тенденцию совладелец и колумнист «Der Spiegel» Я. Аугштайн в 2016 г., когда она окончательно сформировалась в связи с вмешательством России в сирийский конфликт [13]. В период с 2014 до осени 2015 г., когда события на Украине находились в центре внимания западных СМИ, проявились лишь первые признаки указанного тренда. В это время massmedia Европы и Америки, по замечанию Я. Аугштайна, считали В. Путина не столько дьяволом, сколько безумцем мировой политики, живущим, по словам А. Меркель, в параллельной реальности [Там же]. Эволюция образа В. Путина на Западе наглядно прослеживается в тех метафорах, которые использовал журналист в своих статьях разного периода, сравнивая Путина с персонажами из русских сказок. И если в 2015 г. это не такое уж злобное существо, как леший, который убаюкивает русских, грезящих о великой евразийской державе, то в 2017 г. - это уже Баба-Яга, злая лесная ведьма, которая летает по лесу в ступе, заметая свои следы метлой. «На Западе Владимир Путин, подобно Бабе-Яге, является олицетворением зла, корнем всех проблем», - делает вывод Я. Аугштайн [14].

Появление новой тенденции не могло не привести к изменениям в качественных характеристиках имиджа В. Путина хотя бы для того, чтобы выглядеть убедительными ее сторонникам.

Одним из важнейших элементов образа политика, определяющим восприятие его обществом, являются личностные качества. В публикациях изучаемого периода применительно к В. Путину они рассматриваются в нескольких аспектах.

Во-первых, через призму их негативной динамики. Б. Биддер, апеллируя к мнению лидеров западных стран (Г. Шредер, Т. Блэр, Б. Клинтон), с которыми был дружен Путин, обращает внимание на то, что они считали его непростым, но надежным собеседником, который всегда держал слово и отличался знанием деталей и осведомленностью [15]. Однако с начала украинского конфликта, утверждает журналист, обман стал практически постоянным элементом российской политики, и приводит его примеры, начиная от категоричного «не обсуждается» в отношении присоединения Крыма к России, отрицания В. Путиным присутствия военных на референдуме на полуострове, до утверждения, что на востоке Украины против сепаратистов действует «легион НАТО» и у Москвы нет возможности повлиять на ополченцев в Донбассе. Описывая эволюцию речи российского президента через дихотомию честность-лживость, Б. Биддер указывает на две ипостаси последней: большая ложь, к которой Кремль осознанно прибегает, чтобы ввести народ в заблуждение, и мелкие ляпы, которые нередко встречаются в речи российского президента. Гипотетически журналист допускает, что причины этого кроются в недостаточной информированности В. Путина, доступности ему только отфильтрованной собственной пропагандой реальности [15].

На эволюцию со знаком «минус» обращает внимание и упоминавшийся выше Леон Панетта, вспоминая времена, когда с российским президентом можно было договариваться по важным вопросам и даже наблюдались подвижки, на смену которым пришел агрессивный настрой. Источником таких перемен экс-директор ЦРУ считает особенности мышления В. Путина как классического человека спецслужб, стремящегося усилить влияние России в 
бывших республиках СССР, не допустить их сотрудничества с Евросоюзом и удержать от вступления в НАТО [11].

Во-вторых, с точки зрения ключевых качеств президента РФ и их влияния на его политический курс. З. Бжезинский в интервью «Spiegel on-line» выделил три таких качества: инстинктивное чутье, политическая страсть и то, что Путин по натуре - игрок. Рассматривая первые два со знаком «+», он подает их в ракурсе, неблагоприятном для имиджа российского президента: недоумевает, почему он почти умышленно настроил против себя $40 \mathrm{Mлн}$ украинцев, которые до недавнего времени не испытывали к России враждебных чувств; сравнивает В. Путина с Гитлером, когда речь идет о политической страсти, наделяя того и другого этим качеством, одновременно обращая внимание на различие между ними: «Гитлер никогда не был заинтересован в личном обогащении, а Путин в этом очень даже заинтересован. Возможно, именно этот аспект и делает его политическую страсть более умеренной» [6].

Что касается третьей характеристики В. Путина, то американский политик рассматривает ее в качестве наиболее опасной. Заметим, что понятие «игра» встречается довольно часто, когда речь идет о российском президенте. С его помощью характеризуют отношения России и Украины, формулируя их суть в вопросе: «Какую игру на Украине ведет Путин?», отношения России и Запада, которые Л. Панетта охарактеризовал как бесконечную игру В. Путина в одни и те же кошки-мышки, а Я. Аугштайн с сарказмом заметил, что Запад с большой охотой ввязался в покер Владимира Путина [16]. Таким образом, российский президент предстает в качестве доминантного игрока с присущим ему политическим стилем «ставить всех перед жесткими фактами, как это произошло, например, с присоединением Крыма» [17].

Немецкий писатель В. Каминер на страницах «Der Spiegel» обращает внимание на тщеславие главы РФ, хотя и не использует это слово. С иронией упоминает о том, что Путин считает себя европейским политиком и очень трепетно относится к своему имиджу за рубежом; полагает, что российский президент уже долгое время ничего не боится, разве только опозориться; заключает, что на практике имеет место ровно противоположное тому, к чему стремился В. Путин: в глазах населения Европы он превратился в «монстра», «агента зла», и этот ярлык, скорее всего, сохранится за ним даже тогда, когда о нынешнем политическом кризисе уже забудут [18].

В таком же негативном ключе подаются и культурно-символические характеристики президента РФ, которые варьируются в диапазоне от признания его в идейном плане последователем советских вождей, стремящимся к воссозданию неоимперии из бывших союзных республик [19], до объявления наследником фашистов. К такому выводу приходит Я. Фляйшхауэр, проводя параллели со становлением фашизма в Италии: «Там также присутствовал культ тела, патетическая риторика отстаивания своих прав, оценка врага как пришедшего в упадок и деградировавшего, презрение к демократии и западному парламентаризму, раздутый национализм». В подтверждение своей точки зрения журналист обращает внимание на тот факт, что лидеры крайне правых партий видят в Путине человека, разделяющего их идеи, а он, в свою очередь, рассматривает их как «братьев по духу» [20].

Завершая характеристику образа В. Путина в публикациях «Der Spiegel» с позиций его противников, обратим внимание еще на одну отличительную 
их черту - обилие лексических единиц с негативной коннотацией : царь, диктатор, монстр, агент зла, «Путин на пути в ад», бестия, наркоман, постфашист, политический труп, фрик, облеченный властью безумец, непредсказуемый, ненормальный супергерой, могильщик демократии, которые выступают в роли некоей подсказки восприятия В. Путина немецкой аудиторией. Такую же функцию выполняет его сравнение с политическими лидерами, оказавшими негативное воздействие на развитие своей страны.

Как было отмечено во вводной части статьи, немецкий еженедельник представляет широкий спектр мнений о российском президенте. Обратимся к позиции тех, кого принято называть «путинопониматели». Это понятие появилось в связи с присоединением Крыма к России и используется в «Der Spiegel» в отношении, прежде всего, политиков, государственных деятелей и представителей бизнеса Европы и Америки, открыто заявляющих о том, что они понимают В. Путина, в той или иной степени поддерживают его, настроены на сохранение диалога с Россией.

В материалах «Der Spiegel» обращается внимание на весьма обширный и разнородный политический состав этого лагеря: от левых до крайне правых; на причины возникновения этого феномена в Германии: интересы немецкой экономики и бизнеса, страх перед новой «холодной (и не только) войной», тесная историческая связь с Россией, распространенный в мире антиамериканизм, любовь к русской культуре [9]; отсутствие корреляции между пониманием мотивов Путина и одобрением его политики [21]; неэффективность санкций: вряд ли приведут к изменению политического курса В. Путина; ошибки, допущенные Западом в ходе украинского кризиса: отсутствие диалога с Россией в вопросе об ассоциации Украины с Евросоюзом в силу ее особого значения для РФ [8].

В ракурсе такого понимания ситуации выстраивается и имидж российского президента. Акцент в нем смещается в сторону таких его характеристик, которые способны снизить тревожность европейских стран в отношении дальнейшей экспансии России. Так, председатель Германо-российского форума М. Плацек называет В. Путина «очень трезвым и реалистичным политиком» [22], а замглавы фракции «левых» в Бундестаге В. Герке считает, что «не следует недооценивать рациональность российской политики» [21]. Заметим, что на страницах «Der Spiegel» не единожды звучала мысль о том, что «ни один член Североатлантического альянса не ждет классической военной агрессии со стороны России ни в отношении Украины, ни против себя», и это были далеко не люди, понимающие Путина [23].

На позитивное восприятие В. Путина направлены представления о нем как о президенте, который «не позволяет другим странам навязывать ему решения», защищая интересы России и россиян [24]. Правда, не стоит забывать, что звучат они из уст лидера «крайне правых» во Франции Марин Ле Пен, репутация которой весьма неоднозначна в Европе.

В целом описание лагеря «путинопонимателей» в еженедельнике в значительной степени построено на анализе немецкого общества с такими представителями политической и экономической элиты, как экс-канцлеры Г. Шмидт и Г. Шредер; сподвижник курса федерального канцлера В. Бранда по разрядке напряженности с СССР Э. Бар (СДПГ); экс-главный редактор партийной газеты ХСС В. Шарнагль; действующие депутаты от разных пар- 
тий, включая феминисток и зеленых; председатель Восточного комитета немецкой экономики Э. Кордес; председатель Германо-российского форума М. Плацек и др.

Ocoбое место в материалах «Der Spiegel» занимают статьи колумниста Якоба Аугштайна. Точка зрения журналиста выбивается из канвы рассуждений о В. Путине как противников российского президента, так и тех, кто пытается его понять. Не жалуя В. Путина (он, как и в прежние годы, называет его царем), Аугштайн вместе с тем резко выступает против демонизации российского президента, о чем сказано выше; подвергает критике политику двойных стандартов руководства Германии в отношении США и России, усматривая причину этого, помимо прочих, в «русской травме», которую получили президент Й. Гаук и канцлер А. Меркель, будучи выходцами из Восточной Германии [25]; указывает на фактическое бессилие Запада в украинском конфликте на фоне хвастливых заявлений Б. Обамы об эффективности западных санкций, которые разрушили экономику России и привели к ее полной изоляции в мире [26]; возражает против обвинений российского президента в каждом обострении ситуации на Украине, включая трагедию с малазийским «Боингом» [27].

Сбитый «Боинг» сыграл особую роль в украинском конфликте. Примечательна солидарная позиция 9 журналистов «Der Spiegel», которые, апеллируя к мнению политологов, считают катастрофу над Донецком «фактором, изменившим правила игры»: под его влиянием 28 европейских стран приняли решение ввести первые жесткие экономические санкции против России [28]. Я. Аугштайн называет сбитый самолет «апогеем конфликта» по той же причине, но в отличие от авторов статьи, которые говорят о «новой мужественной позиции европейцев», он весьма скептичен в вопросе о предельной ясности с ее виновником и разумности последовавшего ответа: «Месть, - пишет журналист, - витает в воздухе: там, где раныше были разумные решения, теперь есть лишь гнев. Но месть - опасная игра, а гнев не самый лучший советчик». Весьма скептичен и вывод, к которому приходит Аугштайн: «Мировая общественность еще не доросла до нынешнего конфликта между Востоком и Западом. Она полагается на старые рефлексы, которые в прошлом приводили в тупик» [27]. «Скептики» - так мы назвали третью позицию в «Der Spiegel», связанную с конструированием имиджа российского президента в еженедельнике, весьма немногочисленную и представленную, главным образом, Я. Аугштайном. Обращение ко всем трем позволяет составить представление об образе главы РФ в еженедельнике в различных проекциях. При этом, учитывая массив статей, посвященных каждой из позиций, можно сделать вывод, что доминируют негативные составляющие имиджа В. Путина, порой крайне нелицеприятные.

Журналисты «Der Spiegel» обращают внимание на усилия России улучшить внешний имидж страны и ее президента. На это, по оценкам западных и отечественных политиков, функционеров и журналистов, были направлены Сочинская олимпиада, освобождение М. Ходорковского, Чемпионат мира по футболу в России. Так, Г. Киссинджер называет главной задачей олимпиады демонстрацию того, что «Россия является прогрессивным государством, связанным с Западом посредством своей культуры, и, следовательно, она предположительно хотела бы быть его частью» [8]. А. Сорокин (генеральный ди- 
ректор Оргкомитета по подготовке и проведению ЧМ по футболу «Россия2018») рассуждает в этом же направлении, рассматривая проведение ЧМ в РФ как «возможность показать новую Россию, современную и открытую миру» [29]. М. Шепп, апеллируя к содержанию секретного письма экс-министра иностранных дел ФРГ Г.Д. Геншера, сыгравшего решающую роль в освобождении М. Ходорковского, называет в качестве основных мотивов решения Путина о помиловании главы «ЮКОСа» - желание улучшить имидж России [30].

Неудачи с корректированием образа В. Путина и РФ в позитивную сторону журналисты немецкого еженедельника и их собеседники связывают, помимо прочего, с предрассудками, мифами в отношении России. Например, бывший вице-президент Еврокомиссии Г. Ферхойген обращает внимание на широко распространенное представление о том, что Россия возвращается в варварство. Развенчивая этот миф, он обращается и к образу российского президента, утверждая, что «В. Путин - это не восставший из гроба дух Ивана Грозного или Иосифа Сталина» [31].

О тенденциозности и предвзятости по отношению к России говорил в интервью «Der Spiegel» упомянутый выше A. Сорокин, рассматривая клишированные представления о своей стране, которые не соответствуют действительности, но тем не менее искусственно поддерживаются. В частности, о среднестатистическом русском в виде этакого верзилы из голливудских фильмов про Джеймса Бонда, о природе России, где якобы весь год мороз минус десять градусов или больше, о людях, которые не имеют никакого представления о демократии. В пику этому мифу российский функционер замечает, что россияне ничем не отличаются от европейцев, у них те же самые интересы, ценности и мечты [29].

О смаковании «ужасных картинок» из России, перехода критики за все разумные границы писал Б. Биддер по поводу критики Сочинской олимпиады. Не отрицая серьезных недостатков при ее подготовке, журналист резюмирует: «Россия в целом не заслуживает того злорадства, какое появляется у иностранцев при виде неработающей дверной ручки или сломанной скамейки... Злопыхательство оскорбляет их (россиян. - Г.Б.): они организуют праздник, а мы, гости, каждый вечер потягиваем прохладительные напитки, а потом во всю глотку ржем в туалете, что русские опять облажались». К интересному выводу приходит Б. Биддер, практически прогнозируя развитие дальнейших событий: «Некогда российский галерист Марат Гельман высказался в том смысле, что для Запада все будет в порядке, только если из России будут приходить плохие новости. Очень бы хотелось, чтобы Гельман ошибся в своей оценке» [32].

В целом, обобщая результаты исследования имиджа В. Путина в «Der Spiegel» в контексте украинского кризиса, прежде всего присоединения Крыма, следует отметить ключевую роль, которую сыграли эти события в дальнейшей эволюции образа российского президента, задав вектор оценок его внешней политики как определяющего имидж-фактора. Качественные характеристики имиджа президента России в «Der Spiegel» варьируются в зависимости от субъектов конструирования его образа. Противники В. Путина делают акцент на личностные качества и культурно-символические элементы образа российского президента со знаком «минус», которые порой 
предстают в крайне нелицеприятном виде. В лагере «понимающих» Путина ударение ставится на реализм и «трезвый» подход к делу главы РФ для нейтрализации страхов соседей России в отношении ее экспансионистских устремлений. Скептики весьма критично оценивают политику Запада в отношении России, в том числе тенденцию демонизации образа ее президента, попытки сваливать на него ответственность за все мировое зло.

Обращение ко всем трем позициям позволяет составить представление об имидже главы РФ в еженедельнике в различных проекциях и таким образом выйти за пределы устоявшегося представления о том, что западные СМИ лишь демонизируют его образ. Во всяком случае - это не про «Der Spiegel», который с момента основания Аугштайном придерживался принципа объективности и достоверности информации.

\section{Литература}

1. Афонский А. Ни «денег», ни «власти». «Коммерсант» закрывает два журнала // Профиль: сетевой журнал. 2017. URL: https://profile.ru〉Общество >item/114483-kommersant (дата обращения: 18.08.2018).

2. Боброва Г.Е., Комарова И.Н. Трансформация имиджа В. Путина в еженедельнике «Spiegel» (на примере трех президентских избирательных кампаний) // Вестник Томского государственного университета. Философия. Социология. Политология. 2014. № 3. С. 83-96.

3. Сдельников B.A. Роль личности президента В.В. Путина в современном имидже России // Вестник Томского государственного университета. Философия. Социология. Политология. 2016. № 3. С.217-225.

4. Оганесян К.С. Образ В.В. Путина в качественных западных СМИ: по материалам ежедневных газет США, Франции, Германии, Великобритании в 2012-2014 гг.: дис. ... канд. филол. наук. М., 2017. 231 с.

5. Политическая имиджелогия / под ред. А.А. Деркача, Е.Б. Перелыгиной и др. М. : Аспект Пресс, 2006. 400 c.

6. Фишер С., Хольгер Ш. З. Бжезинский: Мы находимся в состоянии «холодной войны». URL: https://inosmi.ru>Mир 20150630/228876356.html (дата обращения: 18.08.2018).

7. Биддер Б.Д. Трамп и В. Путин: признания в любви из Москвы. URL: https:// inopressa.ru>article/25may2016/spiegel/trump_putin (дата обращения: 18.08.2018).

8. Миттельштедт Ю., Фоллат Э. Как обеспечить мировой порядок - через хаос или проникновение в суть? Интервью Г. Киссинджера. URL: https:// inosmi.ru>Мир 20150313/ 226823694.html (дата обращения: 18.08.2018).

9. Нойкирх Р. Проблема с пониманием. URL: https:// inopressa.ruarticle/31mar2014 _..germ rus1.html (дата обращения: 18.08.2018).

10. Хаммеритайн К. Президент Литвы Даля Грибаускайте: «Мы должны всерьез воспринимать паранойю Путина». URL: https:// inosmi.ru>Политика>20160711/237148554.html (дата обращения: 22.08.2018).

11. Экс-глава Пентагона: «Русские понимают только язык силы». URL: https:// expert.ru 2015/02/18/leon-panetta...russkimi-nuzhno... (дата обращения: 22.08.2018).

12. Гебауэр М., Хаммерштайн К., Мюллер П., Шульт К. Риски для НАТО весьма высоки. URL: https:// inosmi.ru>politic/20171026/240622785.html 2015/02/18/leon-panetta...russkiminuzhno... (дата обращения: 05.09.2018).

13. Аугштайн Я. Запад против России: виноват всегда Путин. URL: https:// inosmi.ru>Политика>20160216/235431091.html (дата обращения: 05.09.2018).

14. Аугштайн Я. Путин - Баба-Яга. URL. https:// inosmi.ru>Политика>20171226/ 241092038.html (дата обращения: 05.09.2018).

15. Биддер Б. Верит ли Путин собственной пропаганде. URL: https:// inosmi.ru>Mир> 20150129/225912610.html (дата обращения: 12.09.2018).

16. Аугштайн Я. Война по недоразумению. URL: https:// inopressa.ru〉article/29Apr2014... augstein.html (дата обращения: 12.09.2018).

17. Вайланд C. «Большая семерка» отжила свое. URL: https:// inopressa.ru>article/ 16Apr2015/spiegel/g7_rus.html (дата обращения: 12.09.2018). 
18. Каминер В. Путин - сам себе санкция. URL: https:// inopressa.ru>article/30Jul2014...kaminer.html (дата обращения: 12.09.2018).

19. Биддер Б. Три «опции» Путина. URL: https:// inopressa.ru>article/15apr2014/spiegel/ putin_ukr1 (дата обращения: 19.09.2018).

20. Фляйшхауэр Я. Идеология сверхнарода. URL: https:// inopressa.ru>article/02May2014/ spiegel... (дата обращения: 19.09.2018).

21. Зюдов K. Депутат немецких «левых»: «Понимать позицию России означает всего лишь понять, почему она действует таким образом. Необязательно высказывать одобрение». URL: https:// inopressa.ru>article/1 lapr2014...gehrcke.html (дата обращения: 19.09.2018).

22. Хофманн К., Шепn М. Председатель Германо-российского форума: «Путин-реалист». URL: https:// inopressa.ru>article/19May2014/spiegel/put1.html (дата обращения: 19.09.2018).

23. Гебауэр M., Шульт K., Вигрефе K. Затупленное копье. URL: https:// inopressa.ru>article/01dec2014/spiegel/nato_2 (дата обращения: 23.09.2018).

24. Редакция. Марин Ле Пен: Внимание, госпожа Меркель! URL: https:/ inopressa.ru>article/02jun2014/spiegel/marin (дата обращения: 23.09.2018).

25. Аугштайн $Я$. Плохой русский, хороший американец. URL: https:// inopressa.ru>article/11dec2013/spiegel/... (дата обращения: 23.09.2018).

26. Аугштайн Я. Прощай, старое могущество! URL: https:// inopressa.ru>article/ 20feb2015... augstein.html (дата обращения: 23.09.2018).

27. Аугштайн Я. МH-17: Почему поиск виновных ни к чему не приведет. URL: https:// inopressa.ru>article/25Jul2014/spiegel/crash1.html (дата обращения: 03.10.2018).

28. Биддер Б., Бломе Н., Хессе М., Кнауп Б., Нееф К., Паули К., Зауга М., Шиндлер Й., Шмити Г.П. Позднее пробуждение. URL: https:// inopressa.ru>article/28jul2014/spiegel/rus_1.html (дата обращения: 03.10.2018).

29. Эберле Л., Шеnn M. Алексей Сорокин: «У нас благородные мотивы». URL: https:// inopressa.ru>article/15dec2014/spiegel/sport (дата обращения: 13.10.2018).

30. Шепn M. Секретное дело: Ходорковский. URL: https:// inopressa.ru>article/ 15dec2014...khodorkovsky.html (дата обращения: 03.10.2018).

31. Шепn M. Интервью с Гюнтером Фергойгеном: Путин не призрак Сталина. URL: https:// inosmi.ru>Мир 20150929/230530006.html (дата обращения: 23.10.2018).

32. Биддер Б. Дурацкое злорадство Запада. URL: https:// inopressa.ru>article/10Feb2014/ spiegel/sochi3.html (дата обращения: 23.10.2018).

Galina E. Bobrova, Novokuznetsk Institute (Branch) of Kemerovo State University (Novokuznetsk, Russian Federation).

E-mail: g.bobrova@bk.ru

Vestnik Tomskogo gosudarstvennogo universiteta. Filosofiya. Sotsiologiya. Politologiya - Tomsk State University Journal of Philosophy, Sociology and Political Science. 2020. 56. pp. 243-255.

DOI: $10.17223 / 1998863 X / 56 / 22$

THE EVOLUTION OF THE IMAGE OF VLADIMIR PUTIN IN DER SPIEGEL IN THE CONTEXT OF THE UKRAINIAN CRISIS

Keywords: image of Vladimir Putin; Spiegel; Crimea; demonization; trend; opponents; Putin understanders; skeptics.

At the beginning of 2012, the journalists of Der Spiegel, predicting a difficult third presidential term for Vladimir Putin, focused on the home political situation in Russia, on protest moods and rallies in Moscow and St. Petersburg. But in 2014 the focus of their interest shifted to the field of Russia's foreign policy, which began to play the role of the dominant factor in constructing the image of the Russian president in one of the most important information and political magazines in Germany and Europe. The article aims to identify trends in the evolution of the external image of Vladimir Putin in the weekly Der Spiegel in the context of the most important events of the Ukrainian crisis, first of all, the inclusion of Crimea to Russia, which played a special role in the evolution of the image of the Russian president, setting the vector of foreign policy assessments as the determining factor in the design of this image. On the materials of Der Spiegel, different positions are considered in relation to Russia in the post-Crimean period in Europe and the world. Based on these positions, the author identifies three wings with variations characterizing the components of Putin's image: opponents, "Putin understanders", and skeptics. If the first wing focuses on the personal qualities and cultural-symbolic elements of the image of the Russian president in a negative perspective, sometimes in an extremely unflattering form, the second one emphasizes Putin's realism and "sober" approach to the role in neu- 
tralizing fears of Russia's neighbors about the country's expansionist aspirations. Skeptics are represented mainly by Jakob Augstein, the columnist and co-owner of Der Spiegel, who is very critical in his assessment of the Western policy towards Russia, its tendency to demonize the image of the president, and attempts to shift the responsibility for all the world evil to him. Considering all the three positions contributes to forming a clear view of the image of the head of the Russian Federation in the weekly in various projections and thus to moving beyond the established idea that the Western media only demonize his image: anyway, this is not about Der Spiegel.

\section{References}

1. Afonsky, A. (2017) Ni "Deneg", ni "Vlasti". "Kommersant" zakryvaet dva zhurnala [Neither "Money" nor "Power". "Kommersant" is closing two magazines]. [Online] Available from: https://profile.ru〉Obshchestvo>item/114483-kommersant (Accessed:18th August 2018).

2. Bobrova, G.E. \& Komarova, I.N. (2014) The transformation of the image of V.Putin in the weekly «SPIEGEL» (on the example of the three presidential election campaigns). Vestnik Tomskogo gosu-darstvennogo universiteta. Filosofiya. Sotsiologiya. Politologiya - Tomsk State University Journal of Philosophy, Sociology and Political Science. 3. pp. 83-96. (In Russian).

3. Sdelnikov, V.A. (2016) Role of personality of the President V.V. Putin in the modern image of Russia. Vestnik Tomskogo gosudarstvennogo universiteta. Filosofiya. Sotsiologiya. Politologiya Tomsk State University Journal of Philosophy, Sociology and Political Science. 3. pp. 217-225. (In Russian). DOI: 10.17223/1998863X/35/23

4. Oganesyan, K.S. (2017) Obraz V.V. Putina v kachestvennykh zapadnykh SMI: po materialam ezhednevnykh gazet SShA, Frantsii, Germanii, Velikobritanii v 2012-2014 gg. [The image of V.V. Putin in high-quality Western media: based on the USA, France, Germany, Great Britain daily newspapers in 2012-2014]. Philology Cand. Diss. Moscow.

5. Derkach, A.A., Perelygina, E.B. et al. (ed al.) Politicheskaya imidzhelogiya [Political Imageology]. Moscow: Aspekt Press.

6. Fischer S. \& Holger, Sh. (2015) Z. Bzhezinskiy: My nakhodimsya v sostoyanii kholodnoy voyny [Z. Brzezinski: We are in a cold war]. [Online] Available from: https://inosmi.ru> Mir>20150630/228876356.html (Accessed: 18th August 2018).

7. Bidder, B.D. (2016) Tramp i V. Putin: priznaniya v lyubvi iz Moskvy [Trump and V. Putin: declarations of love from Moscow]. [Online] Available from: https:// inopressa.ru>article/25may2016/ spiegel/trump_putin (Accessed: 18th August 2018).

8. Mittelstedt, J. \& Follat, E. (2015) Kak obespechit' mirovoy poryadok-cherez khaos ili proniknovenie $v$ sut'? Interv'yu G. Kissindzhera [How to ensure world order - through chaos or penetration into the essence? G. Kissinger's interview]. [Online] Available from: https://inosmi.ru>Mir> 20150313/226823694.html (Accessed: 18th August 2018).

9. Neukirch, R. (2014) Problema s ponimaniem [The problem with understanding]. [Online] Available from: https:// inopressa.ru>article/31mar2014...germ_rus1.html (Accessed: 18th August 2018).

10. Hammerstein, K. (2016) Prezident Litvy Dalya Gribauskayte: "My dolzhny vser'ez vosprinimat' paranoyyu Putina" [President of Lithuania Dalia Grybauskaite: "We must take Putin's paranoia seriously"]. [Online] Available from: https:// inosmi.ru>Politika 20160711/237148554.html (Accessed: 22nd August 2018).

11. Ekspert-online. (2015) Eks-glava Pentagona: "Russkie ponimayut tol'ko yazyk sily" [The Pentagon ex-head: "Russians understand only the language of power"]. [Online] Available from: https:// expert.ru>2015/02/18/leon-panetta...russkimi-nuzhno...(Accessed: 22nd August 2018).

12. Gebauer, M., Hammerstein, K., Müller, P. \& Schult, K. (2017) Riski dlya NATO ves'ma vysoki [Risks for NATO are very high]. [Online] Available from: https://inosmi.ruspolitic/20171026/240622785.html 2015/02/18/leon-panetta...russkimi-nuzhno... (Accessed: 5th September 2018).

13. Augstein, J. (2016) Zapad protiv Rossii: vinovat vsegda Putin [West against Russia: Putin is always to blame]. [Online] Available from: https:// inosmi.ru>Politika>20160216/235431091.html (Accessed: 5th September 2018).

14. Augstein, J. (2017) Putin - Baba-Yaga [Putin - Baba Yaga]. [Online] Available from: https:// inosmi.ru>Politika>20171226/241092038.html (Accessed: 5th September 2018).

15. Bidder, B. (2015) Verit li Putin sobstvennoy propagande [Does Putin Believe His Own Propaganda]. [Online] Available from: https:// inosmi.ru〉Mir 20150129/225912610.html (Accessed: 12th September 2018). 
16. Augstein, J. (2014) Voyna po nedorazumeniyu [War of misunderstanding]. [Online] Available from: https:// inopressa.ru>article/29Apr2014...augstein.html (Accessed: 12th September 2018).

17. Vayland, S. (2015) "Bol'shaya semerka” otzhila svoe ["Great Seven" has outlived its own]. [Online] Available from: https:// inopressa.ru>article/16Apr2015/spiegel/g7_rus.html (Accessed: 12th September 2018).

18. Kaminer, V. (2014) Putin - sam sebe sanktsiya [Putin as his own sanction]. [Online] Available from: https:// inopressa.ru>article/30Jul2014...kaminer.html (Accessed: 12th September 2018).

19. Bidder, B. (2014) Tri "optsii" Putina [Three "options" of Putin]. [Online] Available from: https:// inopressa.ru>article/15apr2014/spiegel/putin_ukr1 (Accessed: 19th September 2018).

20. Fleischhauer, J. (2014) Ideologiya sverkhnaroda [Ideology of the supernation]. [Online] Available from: https:// inopressa.ru article/02May2014/spiegel...(Accessed: 19th September 2018).

21. Sydow, K. (2014) Deputat nemetskikh “levykh”: "Ponimat' pozitsiyu Rossii oznachaet vsego lish' ponyat', pochemu ona deystvuet takim obrazom. Neobyazatel'no vyskazyvat' odobrenie [Deputy of the German "leftist": To understand the position of Russia is just to understand why it acts in this way. It is not necessary to give approval]. [Online] Available from: https:// inopressa.ru $>$ article/11apr2014... gehrcke.html (Accessed: 19th September 2018).

22. Hofmann, K. \& Shepp, M. (2014) Predsedatel' Germano-rossiyskogo foruma: "Putinrealist" [Chairman of the German-Russian Forum: "Putin-Realist"]. [Online] Available from: https:// inopressa.ru $>$ article/19May2014/spiegel/put1.html (Accessed: 19th September 2018).

23. Gebauer, M., Schult, K. \& Wigrefe, K. (2014) Zatuplennoe kop'e [Blunt spear]. [Online] Available from: https:// inopressa.ru>article/01dec2014/spiegel/nato_2 (Accessed: 23rd September 2018).

24. Der Spiegel. (2014) Redaktsiya. Marin Le Pen: Vnimanie, gospozha Merkel'! [Editorial. Marine Le Pen: Attention, Mrs. Merkel!]. [Online] Available from: https://inopressa.ru>article/ 02jun2014/spiegel/marin (Accessed: 23rd September 2018).

25. Augstein, J. (2013) Plokhoy russkiy, khoroshiy amerikanets [Bad Russian, good American]. [Online] Available from: https:// inopressa.ru article/11 dec2013/spiegel/... (Accessed: 23rd September 2018).

26. Augstein, J. (2015) Proshchay staroe mogushchestvo! [Farewell to the old power!]. [Online] Available from: https:// inopressa.ru>article/20feb2015...augstein.html (Accessed: 23rd September 2018).

27. Augstein, J. (2014) MN-17: Pochemu poisk vinovnykh ni $k$ chemu ne privedet [MN-17: Why the search for the culprits will not lead to anything]. [Online] Available from: https:// inopressa.ru>article/25Jul2014/spiegel/crash1.html (Accessed: 3rd October 2018).

28. Bidder, B., Blome, N., Hesse, M., Knaup, B., Neef, K., Pauli, K., Zauga, M., Schindler, J. \& Schmitz, G.P. (2014) Pozdnee probuzhdenie [Late awakening]. [Online] Available from: https://inopressa.ru>article/28jul2014/spiegel/rus_1.html (Accessed: 3rd October 2018).

29. Eberle, L. \& Shepp, M. (2014) Aleksey Sorokin: “U nas blagorodnye motivy” [Alexey Sorokin: "We have noble motives"]. [Online] Available from: https://inopressa.ru article/15dec2014/ spiegel/sport (Accessed: 13th October 2018).

30. Shepp, M. (2014) Sekretnoe delo: Khodorkovskiy [A secret case: Khodorkovsky]. [Online] Available from: https:// inopressa.ru>article/15dec2014...khodorkovsky.html (Accessed: 3rd October 2018).

31. Shepp, M. (2015) Interv'yu s Gyunterom Fergoygenom: Putin ne prizrak Stalina [Interview with Gunther Ferhoigen: Putin is not the ghost of Stalin]. [Online] Available from: https://inosmi.ru> Mir 20150929/230530006.html (Accessed: 23rd October 2018).

32. Bidder, B. (2014) Duratskoe zloradstvo Zapada [Foolish malevolence of the West]. [Online] Available from: https:// inopressa.ru>article/10Feb2014/spiegel/sochi3.html (Accessed: 23rd October 2018). 